\section{Infecção pelos vírus linfotrópicos de células T humanas dos tipos I (HTLV-I) e II (HTLV-II) em portadores do HIV em Santos-SP: estudo de prevalência e fatores de risco}

Os vírus linfotrópicos de células T humanas do tipo I (HTLV-I) e do tipo II (HTLV-II) pertencem à família Retroviridae, a qual inclui o vírus da imunodeficiência humana (HIV). HTLV-I, HTLVII e HIV apresentam as mesmas formas de transmissão, resultando em fatores comuns de risco e em sobreposição de populações expostas. Sede do maior porto da América Latina, Santos apresenta uma intensa atividade de prostituição e reúne um grande contingente de usuários de drogas. As doenças de transmissão sexual e sangüínea representam um grave problema de saúde pública para o município. Embora até o momento a ocorrência de doenças atribuíveis às infecções pelo HTLV-I e pelo HTLV-II não tenham uma expressão significativa, do ponto de vista populacional, o estudo dessas infecções pode também proporcionar um melhor conhecimento da epidemiologia e da etiopatogenia de outras doenças que compartilham as mesmas formas de transmissão. O presente estudo foi desenvolvido como um inquérito soroepidemiológico e tem os objetivos de determinar a prevalência das infecções pelo HTLV-I e pelo HTLV-II entre os portadores do HIV atendidos no Centro de Referência em AIDS de Santos-SP, bem como a sua associação com variáveis sociodemográficas, com práticas de risco para a transmissão, com variáveis clínicas e laboratoriais. Das 499 amostras incluídas no estudo e submetidas a dois testes sorológicos de triagem, pelo método de ELISA, 143 amostras positivas ou inconclusivas em pelo menos um destes foram selecionadas para o teste confirmatório pelo método de Western blot. Os testes confirmatórios revelaram 66 $(46,1 \%)$ amostras positivas, 35 (24,5\%) negativas e $42(29,4 \%)$ com padrão indeterminado de reatividade. A discriminação das 66 amostras reagentes mostrou 29 (44\%) com padrão

\section{Human T-cell lymphotropic virus types I (HTLV-I) and II (HTLV-II) infections in HIV- infected individuals in Santos, SP: seroprevalence and risk factors}

Human T-cell lymphotropic virus types I (HTLV-I) and II (HTLV-II) are members of the Retroviridae family, which also includes the human immunodeficiency virus (HIV). HTLV-I, HTLV-II and HIV share the same modes of transmission and risk factors. Thus an overlapping in exposure to these retroviruses is expected. The municipality of Santos, SP, where the largest port in Latin America is located, has large numbers of female sex-workers and intravenous drug-users. Therefore, sexually and blood-borne transmitted diseases constitute a serious local public-health issue. To evaluate the seroprevalence of HTLV-I and HTLV-II infections and their risk factors, a cross-sectional survey was conducted on 499 HIV-infected individuals from Santos, SP. Sero-screening with two ELISA tests resulted in 143 seropositive or inconclusive samples, which were then submitted to a Western-blot confirmatory test. Western blots revealed 66 (46.1\%) seropositive, 35 (24.5\%) seronegative and $42(29.4 \%)$ sero-indeterminate samples, and also discriminated $29(44 \%)$ seropositive samples as compatible with HTLV-I infection, $36(54.5 \%)$ with HTLV-II infection and one (1.5\%) with HTLV-I and HTLV-II co-infection. HTLV-I and HTLV-II seroprevalences were $6 \%$ (Cl 95\%, 3.9-8.1) and 7.4\% (Cl 95\%, 5.1-9.7), respectively. Multivariate logistic regression for statistical analysis revealed that HTLV-I infection was independently associated with: intravenous drug use $(\mathrm{OR}=2.99 ; \mathrm{Cl} 95 \%, 1.09-8.20)$, HCV seropositivity $(\mathrm{OR}=3.03 ; \mathrm{Cl} 95 \%, 1.02-9.01)$ and less then 3 years of formal education $(\mathrm{OR}=4.73$; CI 95\%, 1.56-14.41). HTLV-II infection was associated with: intravenous drug use $(\mathrm{OR}=3.32$; $\mathrm{Cl} 95 \%, 1.33-7.84)$, HCV seropositivity (OR = $5.40 ; \mathrm{Cl} 95 \%, 1.86-15.66)$ and non-white individuals $(\mathrm{OR}=3.32 ; \mathrm{Cl} 95 \%, 1.58-7.00)$. The

Recebido para publicação em 20/7/99. 
sorológico de infecção pelo HTLV-I, 36 (54,5\%) com padrão sorológico de infecção pelo HTLV-II e uma (1,5\%) amostra com padrão de coinfecção pelo HTLV-I e pelo HTLV-II. A soroprevalência geral da infecção pelo HTLV-I foi de 6,0\% (IC 95\%, 3,9-8,1) e da infecção pelo HTLV-II foi de 7,4\% (IC 95\%, 5,1-9,7). A análise multivariada por regressão logística indicou associação significativa da infecção pelo HTLV-I com o uso de drogas endovenosas (OR $=2,99$; IC 95\%, $1,09-8,20)$, com a soropositividade anti-VHC (OR = 3,03; IC 95\%, 1,02-9,01) e com tempo de escolaridade inferior a três anos $(\mathrm{OR}=4,73$; IC 95\%, 1,56-14,41). A infecção pelo HTLV-II se associou ao uso de drogas endovenosas (OR = 3,32 ; IC 95\%, 1,33-7,84), à soropositividade antiVHC (OR $=5,40$; IC 95\%, 1,86-15,66) e aos indivíduos não brancos (OR = 3,32; IC 95\%, 1,58$7,00)$. Os dados confirmam uma alta circulação e de forma equivalente das infecções pelo HTLVI e pelo HTLV-II no município de Santos. As taxas mostram que a população de portadores do HIV atendida no Centro de Referência em AIDS de Santos exibe características de risco próprias de uma alta exposição a esses retrovírus. Os resultados indicam o uso de drogas endovenosas como o principal fator preditivo do risco de transmissão da infecção pelo HTLV-I e pelo HTLV-II. Não houve associação dessas infecções com fatores de risco de transmissão sexual. $O$ estudo ilustra a complexidade de se determinar o algoritmo ideal para o diagnóstico em triagem e confirmação da infecção pelo HTLV-I/II, principalmente em regiões tropicais e em populações com alta freqüência da infecção pelo HTLV-II. results indicate that HIV-infected individuals living in Santos, SP are at high and similar risk to be exposed to HTLV-I and HTLV-II infections. Intravenous drug use constitutes the main predictive risk factor for HTLV-I and HTLV-II transmission in this population, and there was no significant risk associated with sexual practice. The study also illustrates the complexity in establishing an adequate screening and confirmatory algorithm for HTLV-I/II diagnostic tests, mainly in tropical areas and in regions where HTLV-II infection occurs frequently.

\author{
Arnaldo Etzel \\ Tese apresentada à Faculdade de Medicina da \\ Universidade de São Paulo para obtenção \\ do Título de Mestre.
}

